\title{
Food and habitat choice in the spider crab Leucippa pentagona (Majoidea: Epialtidae) in Bahía Bustamante, Patagonia, Argentina
}

\author{
Martin Varisco ${ }^{1}$, Lucas Martín ${ }^{2,3}$, Héctor Zaixso ${ }^{1}$, Cecilia Velasquez ${ }^{1}$, Julio Vinuesa ${ }^{1,3}$ \\ ${ }^{1}$ Instituto de Desarrollo Costero, Universidad Nacional de la Patagonia San Juan Bosco, Ruta Provincial 1 Km 4, \\ Comodoro Rivadavia, Chubut, Argentina. (CP 9005). E-mail: martinvarisco@hotmail.com \\ ${ }^{2}$ Laboratorio de Ficología y Micología, Departamento de Biología, Bioquímica y Farmacia, Universidad Nacional del Sur, \\ San Juan 670, Bahía Blanca, Buenos Aires, Argentina (CP B8000CTX). \\ ${ }^{3}$ Consejo Nacional de Investigaciones Científicas y Técnicas de la República Argentina
}

\begin{abstract}
Summary: The aim of the present study was to analyse the feeding strategy and spatial distribution of the spider crab Leucippa pentagona in Bahía Bustamante (Patagonia, Argentina). Several microhabitat variables that could influence the spatial distribution of this crab were related to its different life stages by using redundancy analysis. Regarding its feeding preferences, we found that the sphacelariales Halopteris spp. and Sphacelaria fusca, epiphytes of the alga Gracilaria gracilis, represented over $70 \%$ of its diet. Conversely, consumption of G. gracilis was low throughout the year. These feeding preferences can be related to the higher proportion of ash-free dry mass of sphacelariales. A close association was observed between G. gracilis biomass and recruits and mature crabs; this relationship was stronger at critical periods of the crab's life cycle such as incubation or moult. Intermolt juveniles were related to G. gracilis as well as to other species of macroalgae. Our results suggest that G. gracilis plays a key role in the small-scale distribution of L. pentagona in Bahía Bustamante, providing food and shelter. The consumption of G. gracilis epiphytes allows L. pentagona to maintain high foraging rates at safe living sites, minimizing the damage to G. gracilis.
\end{abstract}

Keywords: Leucippa pentagona; Gracilaria gracilis; microhabitat; subtidal beds; epiphyte consumption; Sphacelariales.

Alimentación y selección del hábitat en el cangrejo araña Leucippa pentagona (Majoidea: Epialtidae) en Bahía Bustamante, Patagonia, Argentina

Resumen: En este trabajo se analiza la alimentación y distribución especial del cangrejo araña Leucippa pentagona en Bahía Bustamante (Patagonia, Argentina). La distribución espacial de distintos estadios del ciclo de vida de la especie se relacionó con variables ambientales mediante un análisis de redundancias. La especie presenta una dieta especializada, las sphacelariales Halopteris spp. y Sphacelaria fusca, epifitas de Gracilaria gracilis, representan más del 70\% de la dieta. Por otra parte, se observó una baja incidencia de G. gracilis en la dieta durante todas las estaciones del año. Estos resultados pueden estar relacionados con el alto contenido de materia orgánica que tienen las sphacelariales. Respecto de la distribución espacial, se observó una relación significativa entre la biomasa de G. gracilis y reclutas y adultos de L. pentagona; esta relación es más significativa en periodos críticos del ciclo de vida del cangrejo como la muda o la incubación de los huevos. Los juveniles de tallas más grandes, en intermuda, están asociados tanto a G. gracilis como a otras macroalgas disponibles en el área. Nuestros resultados sugieren que $G$. gracilis tiene un rol importante en la distribución a pequeña escala del cangrejo L. pentagona en Bahía Bustamante, proveyéndole alimento y refugio. El alto consumo de epifitas de G. gracilis permite a $L$. pentagona alimentarse en el complejo microhabitat que le provee el alga, minimizando el daño sobre G. gracilis.

Palabras clave: Leucippa pentagona; Gracilaria gracilis; microhabitat; dieta; epifitas; Sphacelariales.

Citation/Como citar este artículo: Varisco M., Martín L., Zaixso H., Velasquez C., Vinuesa J. 2015. Food and habitat choice in the spider crab Leucippa pentagona (Majoidea: Epialtidae) in Bahía Bustamante, Patagonia, Argentina. Sci. Mar. 79(1): 107-116. doi: http://dx.doi.org/10.3989/scimar.04060.29B

Editor: J.A. Cuesta.

Received: March 19, 2014. Accepted: October 15, 2014. Published: January 8, 2015.

Copyright: (0 2015 CSIC. This is an open-access article distributed under the Creative Commons Attribution-Non Commercial Lisence (by-nc) Spain 3.0. 


\section{INTRODUCTION}

Seaweed assemblages with a high structural complexity are associated with a wide diversity of benthic invertebrates. Macroalgae play a role in the small-scale distribution and abundance of several decapod species because they provide shelter and food support (e.g. Hines 1982, García-Raso and Fernández-Muñoz 1987, Robinson and Tully 2000, Moksnes 2002, López De La Rosa et al. 2006, Cruz-Rivera and Friedlander 2011, Hammann et al. 2013). Habitat selection and feeding preferences are closely related, particularly in small herbivores (mesograzers) (Nicotri 1980, Duffy and Hay 1994, Mancinelli and Rossi 2001). In this respect, some studies have suggested that food selection is subordinated to structural complexity of seaweed assemblages, because predation risk is the main selection pressure in coastal areas (Duffy and Hay 1991, Taylor and Brow 2006). Habitat requirements of decapod species can change because species are more vulnerable to predation in periods such as settlement, recruitment, incubation and post-moult. However, information about shelter requirements refers mainly to recruitment (e.g. Herrkind and Buttler 1986, Rodríguez et al. 1993, Perkins-Visser et al. 1996, Moksnes 2002).

Knowledge on the feeding preferences of mesograzers is crucial to understand their effects on the algal community. Field experiments have shown that mesograzer feeding is insufficient to control algal biomass (Poore et al. 2009). However, the use of algae as shelter and food can impose constraints on the amount of food available for consumption in order to maintain the integrity of the shelter (Duffy and Hay 1991, Stachowicz and Hay 1996). In particular, beds of Gracilaria spp., which are widely distributed around the world, provide refuge and food to a wide variety of mesograzers such as amphipods, isopods, and crabs (Mancinelli and Rossi 2001, Cruz-Rivera and Friedlander 2011, Hammann et al. 2013). Trophic interactions between Gracilaria spp. and associated mesograzers are variable. Some mesograzers exploit Gracilaria as a food resource, while others prefer feeding on epiphytes or associated macroalgae (Anderson et al. 1998, Mancinelli and Rossi 2001, Smit et al. 2003, Cruz-Rivera and Friedlander 2011, Hammann et al. 2013). Feeding primarily on epiphytes is a feeding behavior that helps to maintain the structural complexity of shelters (Stachowicz and Hay 1996, Boström and Mattilla 1999) and can be indirectly beneficial to Gracilaria spp. populations (Shacklock and Doyle 1983, Anderson et al. 1998). In Argentine Patagonia, G. gracilis forms large and dense beds at some wave-protected sites of Golfo San Jorge (Bahía Bustamante, Puerto Melo and Bahía Arredondo) and Golfo Nuevo. Beds in Bahía Bustamante are the most important in terms of extension and biomass (Martin et al. 2011). However, these beds have significant biomass variation that could be attributed to higher abundance of epiphytes and epiphyte-imposed stress (Martin et al. 2013). No ecological information about these $G$. gracilis beds and associated mesograzers has so far been reported.
In an earlier study, we reported that the epialtid crab Leucippa pentagona is very abundant in Bahía Bustamante (Varisco and Vinuesa 2011). Crabs belonging to the family Epialtidae are mainly mesograzers and commonly inhabit subtidal algal assemblages (Vernet-Cornubert 1958, Hines 1982, García-Raso and FernándezMuñoz 1987, Monteiro-Teixeira et al. 2009, Hultgren and Stachowicz 2008). L. pentagona has been found in algal and mytilid banks of the Southern Atlantic Ocean (Boschi et al. 1992). Although this species is widely distributed from California to southern Chile in the Pacific Ocean, and from Brazil to Argentine Patagonia ( $45^{\circ}$ LS) in the western Atlantic Ocean, many aspects of its biology and ecology are poorly understood. The ecological information available about $L$. pentagona refers only to larval development (Pohle and Marques 2003) and reproductive traits (Varisco and Vinuesa 2011).

This study examines the feeding preferences and habitat choice of L. pentagona in Bahía Bustamante. It also analyses the nutritional quality of $G$. gracilis, its epiphytes and other macroalgae abundant in the study area to explain the food choice of these spider crabs. Finally, it analyses the spatial and temporal distribution of different stages of the crab's life cycle (recruits, juveniles, matures, ovigerous females and post-moult crabs) in relation to biotic and abiotic factors. We hypothesized that: (1) G. gracilis plays a key role in the spatial distribution of $L$. pentagona, particularly during critical periods of its life cycle such as recruitment, egg incubation and early post-moult; and (2) L. pentagona does not exploit $G$. gracilis because it has lower nutritional value than its epiphytes and other macroalgae of the area. This feeding strategy could be indirectly favorable to $G$. gracilis growth and could help to maintain the complexity of the microhabitat.

\section{MATERIALS AND METHODS}

\section{Study area and sampling}

Bahía Bustamante $\left(45^{\circ} 08^{\prime} \mathrm{S}, 66^{\circ} 32^{\prime} \mathrm{W}\right)$ is an enclosed bay located in the north of Golfo San Jorge, in the Argentine Patagonia (Fig. 1). The area is influenced by the cold-temperate waters of the Patagonian Current and, occasionally, by the warmer waters of the Brazilian Current during the summer. The bay has a semidiurnal tidal regime, with average amplitude of $4.2 \mathrm{~m}$. There are dense patches of the economically important red alga Gracilaria gracilis. In recent years, the alien alga Undaria pinnatifida have been found in coastal areas of the bay (Martin et al. 2011).

Sampling and field measurements were taken monthly over a two-year period between March 2006 and February 2008 (with exceptions of April 2006, and March, June and December 2007). Sampling was carried out in low tidal conditions (diurnal). Samples $\left(0.25 \mathrm{~m}^{2}\right)$ were collected by scuba diving along four transects parallel to the coastline at 2, 4, 6 and $8 \mathrm{~m}$ depth below mean low water. In each transect, five sampling units were carried out at $100 \mathrm{~m}$ intervals (totaling 20 per month). Sampling units were considered to be independent because they were separated by at 


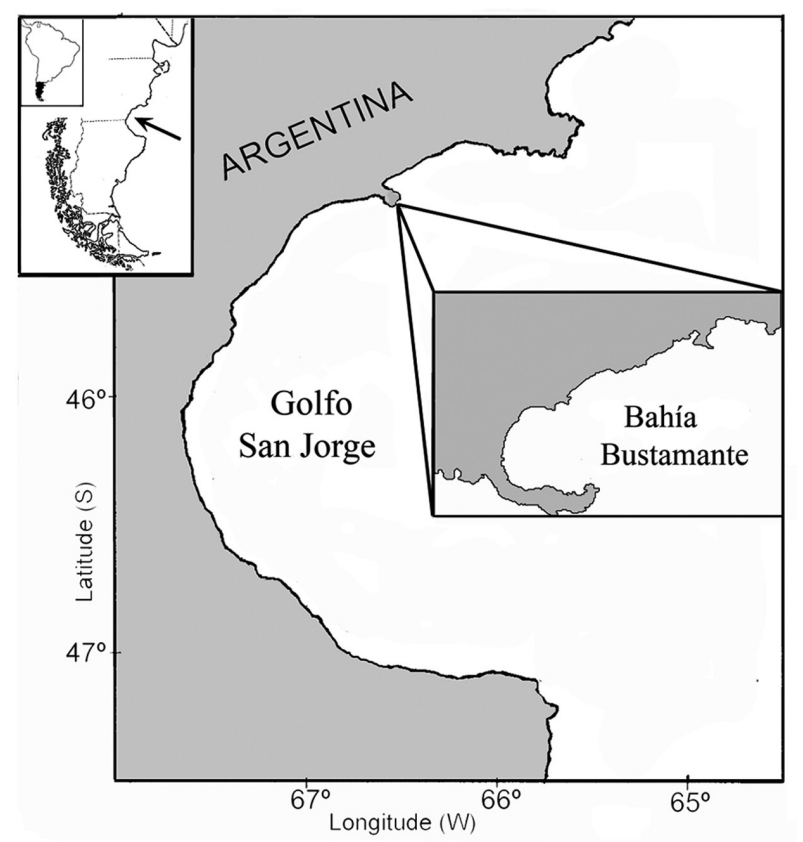

Fig. 1. - Bahía Bustamante, southwestern Atlantic Ocean.

least $100 \mathrm{~m}$. All animals and algae were collected using a nylon mesh bag ( $5 \mathrm{~mm}$ aperture), stored in sealed bags and subsequently fixed in $4 \%$ formalin.

Temperature, salinity and $\mathrm{pH}$ data were recorded using a YSI multiparameter device. In March 2006, sediment samples were taken next to each sampling unit using plastic corers $\left(500 \mathrm{~cm}^{3}\right)$. At rocky sites, no sediment samples were taken and the type of substrate was recorded by direct observation of the diver.

\section{Laboratory procedures and statistical analysis}

\section{Diet analysis}

Samples from January, April, July and October 2007 were selected to perform diet analyses. Crabs were sexed and carapace length (CL) was measured from the tip of the rostrum to the posterior margin of the carapace using a digital calliper $( \pm 0.01 \mathrm{~mm})$. Crabs were grouped into three classes according to morphometric criteria (Varisco and Vinuesa 2011): a) recruits ( $\leq 10 \mathrm{~mm} \mathrm{CL}$ ); b) late juveniles (>10-18 mm CL for females; >10-28.5 mm CL for males); and c) mature crabs. Crabs were dissected and stomach contents were removed under a stereoscopic microscope (40x). Stomach fullness was estimated by visually assessing the percentage of stomach volume occupied by the contents. Each stomach was categorized as follows: class 0 (empty), class 1 (0-25\% fullness), class 2 (25$50 \%)$, class $3(50-75 \%)$, and class $4(75-100 \%)$.

The relative abundance of food items in the natural diet was calculated using an ocular grid marked with 25 intersection points. Stomach contents were examined under a microscope $(100 \times)$ and relative abundance was calculated as $\operatorname{RA}(\%)=\left(I_{a} / T\right) \cdot 100$, where $I_{a}$ is the frequency of intersections for an item and $\mathrm{T}$ is the total number of intersections. The frequency of occurrence of each item was $\mathrm{FO}(\%)=\left(\mathrm{N}_{\mathrm{i}} / \mathrm{N}_{\mathrm{t}}\right) 100$, where $\mathrm{N}_{\mathrm{i}}$ is the number of stomachs with item $\mathrm{i}$ and $\mathrm{N}_{\mathrm{t}}$ is the total number of stomachs. Each food item was determined at the lowest possible taxonomic level.

The independence $\chi^{2}$ test was used to analyse independence between stomach fullness and factors: season, sex, size class and moult stage. One-way analysis of similarity (ANOSIM) tests were performed to assess changes in RA in relation to season, sex, size and moult stage of crabs. The similarity matrix was calculated using the Bray-Curtis similarity index (Clarke and Warwick 2001).

\section{Nutritional quality of algae}

The nutritional quality of algae was assessed using the ash-free dry mass (AFDM) as an approximation for nutritional content of algal species (Cruz-Rivera and Hay 2000, Cruz-Rivera and Friedlander 2011, 2013). This trait was measured in G. gracilaria, Sphacelaria fusca, Halopteris sp., Ceramium virgatum, Undaria pinnatifida and Codium fragile. AFDM is shown as percentage of the wet mass, which is how mesograzers perceive algae, following the criteria proposed by Cruz-Rivera and Friedlander (2011). Thalli of algal species $(n=10)$ were dried on absorbent paper and subsequently weighed (wet mass) $( \pm 0.001 \mathrm{~g})$. Dry mass was obtained after drying at $60^{\circ} \mathrm{C}$ for $48 \mathrm{~h}$. Ash weight was obtained by burning the dried algae in a furnace at $450^{\circ} \mathrm{C}$ for $24 \mathrm{~h}$.

Differences in AFDM mean values among algal species were evaluated by one-way analysis of variance (ANOVA), followed by Tukey post hoc test. Data were previously tested for variance homogeneity (Cochran's Test). A significance level of 0.05 was used in these tests.

\section{Spatial distribution}

Crabs were sexed, measured and grouped according to the procedures and criteria mentioned. Ovigerous females and post-moult crabs were quantified separately. The distribution pattern of each group of interest was evaluated using the standardized Morisita index. This index is one of the best measures of dispersion because it is independent of sample size and population density (Smith-Gill 1975).

For each sampling unit, thalli of G. gracilis, largesized epiphytes and other macroalgae were separated under a stereoscopic microscope. Algal species were dried on absorbent paper and weighed $( \pm 0.001 \mathrm{~g})$. Animal taxa were determined at the lowest taxonomic level possible. All animals in each taxon were counted, except for the solitary ascidian Paramolgula gregaria, which was weighed out $( \pm 0.001 \mathrm{~g})$. Sediment samples were analysed using the grain-size approach (Wentworth 1922) and three fractions were separated (silt/ clay, sand, gravel) and weighed in the laboratory.

A partial redundancy analysis (pRDA) was performed to relate the densities of the different groups of L. pentagona to physical and biological variables (ter Braak 1986). A previous detrended canonical correspondence analysis (DCCA) was conducted to cal- 
culate the gradient length and to verify whether pRDA was the right procedure (ter Braak 1995). The abiotic factors incorporated in the analysis were a) substrate type, treated as a quantitative variable as recommended by ter Braak and Looman (1995), b) months, treated as circular data, and transformed into two orthogonal quantitative variables: "summerness" and "springness" (Palmer 2011), and c) depth, temperature, salinity and $\mathrm{pH}$, as quantitative variables. The biological factors incorporated in pRDA were: a) drained wet biomass of $G$. gracilis, b) drained wet biomass of large-sized epiphytes on $G$. gracilis, c) drained wet biomass of other macroalgae, d) wet biomass of the ascidian $P$. gregaria, e) density of invertebrate prey of $L$. pentagona, f) density of the crab Halicarcinus planatus, g) density of other decapods, and h) density of potential predators. These last variables were selected according to the following criteria: a) macroalgae and ascidians help to create structurally complex habitats which reduce predation risk and dampen current flow, two factors that are particularly important for crab recruitment (Rodríguez et al. 1993); b) food availability is important for the habitat selection of several decapod species (Rodríguez et al. 1993) (the preliminary diet analysis of L. pentagona supports the inclusion of epiphytic algal species on $G$. gracilis and small invertebrate prey of $L$. pentagona); and c) densities of $H$. planatus, other decapods and predators were considered to include aspects of predation and competition. The effect of predation was probably underestimated due to the sampling method used, which did not enable the sampling of larger fish and highly mobile predators. The density of $H$. planatus was particularly considered because of its great abundance in the study area.

The sampling year was entered in the model as a covariable. Analysis was made using inter-species correlation scaling, species scores divided by standard deviation, centering by species and square-root transformation of data. No centering/standardization by samples was used. A subsequent manual forward selection of the variables with $\mathrm{p}<0.01$ was done using Monte-Carlo permutation tests (9999 permutations under a full model).

\section{RESULTS}

\section{Diet analysis}

Of the 163 spider crabs analysed, $23.92 \%$ exhibited full stomachs, $23.31 \%$ exhibited stomachs of class $3,22.69 \%$ exhibited stomachs of class 2 and $15.95 \%$ exhibited stomachs of class 1. Empty stomachs were observed in $14.11 \%$ of crabs (Fig. 2). Crabs in postmoult (soft carapace) had empty stomachs throughout the study period. Stomach fullness was independent of the season, sex and size, although it was related to the moult stage (Table 1).

Forty-five items were identified in the diet of $L$. pentagona, of which 25 were algal species (Table 2). In most cases, the diet items were highly fragmented as a result of the combined physical action of chelipeds, mouthparts and gastric mill. The diet was character-
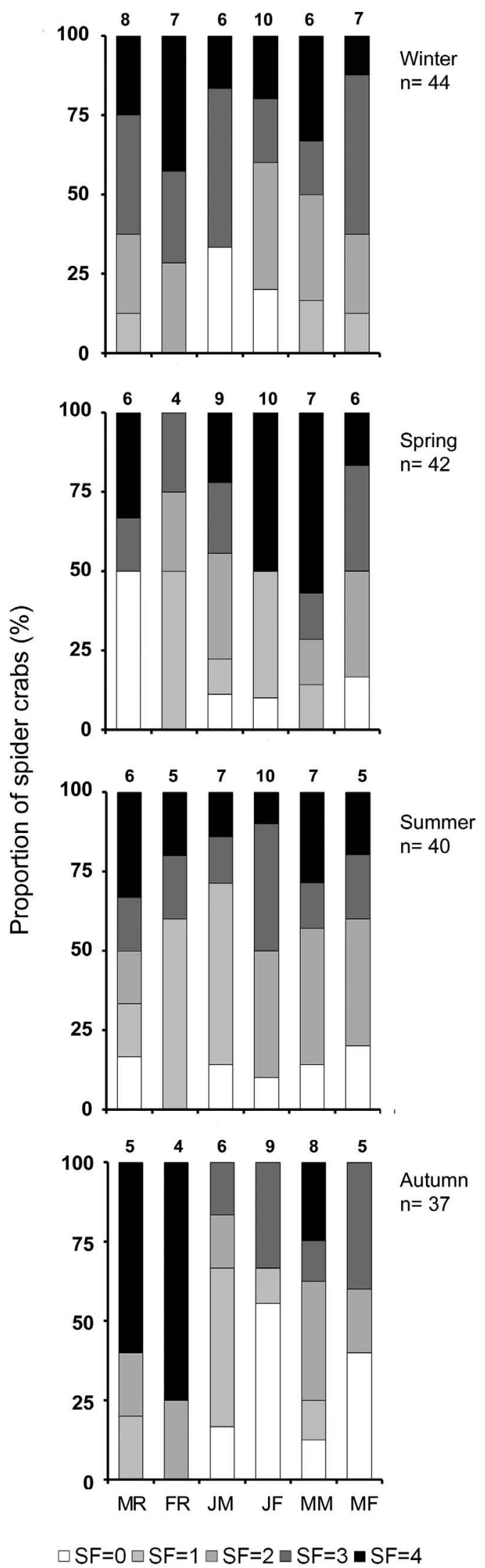

Fig. 2. - Proportion (\%) of Leucippa pentagona in different categories of stomach fullness (SF). MR male recruits, FR female recruits, JM juvenile males, JF juvenile females, MM mature males, MF mature females. Numbers on the top refer to number of specimens in each category. 
Table 1. - Summary of chi-square test of independence between stomach fullness class of spider crabs Leucippa pentagona and factors: seasons, sex, size and moult stage. Chi-square statistics $\left(\chi^{2}\right)$, degrees of freedom (df) and p-value (p). Significance $\mathrm{p}<0.01$.

\begin{tabular}{lccc}
\hline & $\chi^{2}$ & df & $\mathrm{p}$ \\
\hline Seasons & 11.28 & 12 & 0.50 \\
Sex & 4.41 & 4 & 0.35 \\
Size & 0.87 & 8 & 0.99 \\
Moult stage & 121.8 & 4 & 0.001 \\
\hline
\end{tabular}

Table 2. - Taxa identified in the stomach content of Leucippa pentagona individuals in Bahía Bustamante.

\begin{tabular}{|c|c|}
\hline $\begin{array}{l}\text { CYANOPHYTA } \\
\text { Chroococcus sp. } \\
\text { Calothrix confervicola } \\
\text { Cyanophyta indet. }\end{array}$ & $\begin{array}{l}\text { BRYOZOA } \\
\text { Beania inermis } \\
\text { Membranipora isabelleana } \\
\text { Bryozoa indet. }\end{array}$ \\
\hline $\begin{array}{l}\text { CLOROPHYTA } \\
\text { Ulva } \mathrm{sp} . \\
\text { Enteromorpha } \mathrm{sp} . \\
\text { Chaetomorpha } \mathrm{sp} . \\
\text { Ulothrix australis } \\
\text { Codium fragile }\end{array}$ & $\begin{array}{l}\text { FORAMINIFERA } \\
\text { Elphidium sp. } \\
\text { Lagena } \mathrm{sp} . \\
\text { Pyrgo } \mathrm{sp} . \\
\text { Oolina sp. } \\
\text { Cassidulina sp. }\end{array}$ \\
\hline $\begin{array}{l}\text { RHODOPHYTA } \\
\text { Aglaotamnion uruguayense } \\
\text { Anotrichium furcellatum } \\
\text { Ceramium strictum } \\
\text { Ceramium virgatun } \\
\text { Polysiphonia abcisa } \\
\text { Heterosiphonia merenia } \\
\text { Aphanocladia robusta } \\
\text { Lomentaria clavellosa } \\
\text { Gracilaria gracilis }\end{array}$ & $\begin{array}{l}\text { BIVALVIA } \\
\text { Mytilus edulis } \\
\text { Aulacomya atra } \\
\\
\text { ISOPODA } \\
\text { Serolis } \mathrm{sp} . \\
\text { Exosphaeroma } \mathrm{sp} . \\
\text { Idotea baltica } \\
\text { Neastacilla falklandica }\end{array}$ \\
\hline $\begin{array}{l}\text { PHAEOPHYTA } \\
\text { Sphacelaria fusca } \\
\text { Halopteris sp. } \\
\text { Ectocarpus constanciae } \\
\text { Ectocarpus exiguus } \\
\text { Ectocarpus siliculosus } \\
\text { Styphocaulon funiculare } \\
\text { Dictyota dichotoma } \\
\text { Undaria pinnatifida }\end{array}$ & $\begin{array}{l}\text { AMPtroregia huxleyana } \\
\text { Gondogeneia sp. } \\
\text { Amphipoda indet. } \\
\text { COPEPODA } \\
\text { Porcellidium sp. }\end{array}$ \\
\hline
\end{tabular}

ized by the high FO and RA of Sphacelaria fusca and Halopteris sp. Other seaweed species that were important components of the diet in terms of FO were G. gracilis, Ectocarpus spp., Lomentaria clavellosa, Calothrix confervicola and Ceramium spp. To differentiate some algal species, it is necessary to look at the ramifications, reproductive structure or apex. This was

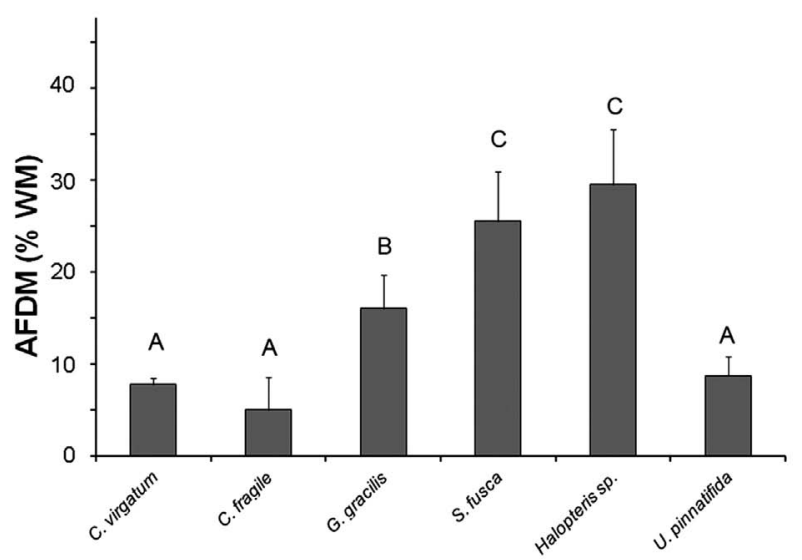

Fig. 3. - Ash-free dry mass in six macroalgal species of Bahía Bustamante expressed in terms of wet mass percentages. Homogeneous group (Tukey post hoc test) and standard error bars are shown.

not always possible in the stomach contents and therefore these species were grouped into a larger category as Sphacelariales, Ectocarpus spp. and Ceramium spp. Among invertebrates, crustaceans, polychaetes and bryozoans were the most abundant and frequent taxa (Table 3). Five species of Foraminifera were found in the crab's diet, but their FO and RA were lower. No differences were found in the diet composition between seasons (ANOSIM $\mathrm{R}=0.008, \mathrm{p}=0.33$ ), sex $(\mathrm{R}=0.009, \mathrm{p}=0.13)$ and size class $(\mathrm{R}=0.038, \mathrm{p}=0.10)$ of these spider crabs.

\section{Nutritional quality of algae}

The AFDM showed significant differences between the algal species analysed with respect to wet mass (one-way ANOVA, $\mathrm{F}_{(5,51)}=45.16, \mathrm{p}<0.01$ ). The highest AFDM values were recorded for Sphacelaria fusca and Halopteris sp (Fig. 3).

\section{Spatial distribution}

\section{Environmental and biological variables}

Some physicochemical properties of the sea water in the bay showed seasonal variations. Variations

Table 3. - Frequency of occurrence (FO) and relative abundance (RA) of the main food items of L. pentagona in G. gracilis beds of Bahía

\begin{tabular}{|c|c|c|c|c|c|c|c|c|}
\hline \multirow{2}{*}{ Food ítems } & \multicolumn{2}{|c|}{ Winter } & \multicolumn{2}{|c|}{ Spring } & \multicolumn{2}{|c|}{ Summer } & \multicolumn{2}{|c|}{ Autumn } \\
\hline & $\mathrm{FO}$ & RA & FO & RA & $\mathrm{FO}$ & RA & $\mathrm{FO}$ & RA \\
\hline Sphacelariales & 72.7 & 67.5 & 85.7 & 72.3 & 82.5 & 70.1 & 78.3 & 67.3 \\
\hline Ectocarpus spp. & 9.09 & 1.39 & 16.6 & 1.05 & 5.00 & 0.23 & 0 & 0 \\
\hline Ceramium spp. & 6.81 & 0.46 & 11.9 & 3.18 & 10.0 & 0.23 & 0 & 0 \\
\hline Calothrix confervicola & 9.09 & 0.92 & 42.8 & 0.17 & 5.00 & 0.23 & 13.5 & 0.51 \\
\hline Gracilaria gracilis & 13.6 & 4.17 & 11.9 & 1.40 & 10.0 & 0.70 & 24.3 & 0.25 \\
\hline Lomentaria clavellosa & 11.3 & 0.92 & 9.52 & 0.35 & 14.0 & 0.50 & 13.5 & 0.25 \\
\hline Other algae & 15.9 & 2.30 & 33.3 & 3.18 & 32.5 & 7.0 & 54.0 & 5.41 \\
\hline Idotea balthica & 4.54 & 1.86 & 0 & 0 & 5.00 & 0.51 & 0 & 0 \\
\hline Austroregia huxleyana & 4.54 & 1.30 & 0.42 & 0.17 & 5.00 & 0.23 & 18.9 & 1.02 \\
\hline Copepoda & 9.09 & 1.27 & 0.84 & 0.29 & 7.50 & 0.51 & 0 & 0 \\
\hline Crustaceans indet. & 15.9 & 2.09 & 1.26 & 1.83 & 10.0 & 1.82 & 21.6 & 2.72 \\
\hline Platynereis sp. & 11.3 & 2.30 & 16.6 & 3.18 & 7.50 & 2.87 & 35.1 & 3.09 \\
\hline Polychaetes indet. & 9.09 & 0.92 & 7.69 & 1.96 & 2.50 & 0.23 & 13.5 & 2.72 \\
\hline Bryozoans & 6.81 & 0.23 & 15.4 & 0.35 & 12.5 & 0.23 & 35.1 & 1.02 \\
\hline Unidentified material & 20.4 & 5.80 & 7.69 & 0.88 & 12.5 & 9.47 & 24.3 & 3.09 \\
\hline Sediment & 20.4 & 6.48 & 38.4 & 9.54 & 14.0 & 5.09 & 35.1 & 12.6 \\
\hline
\end{tabular}



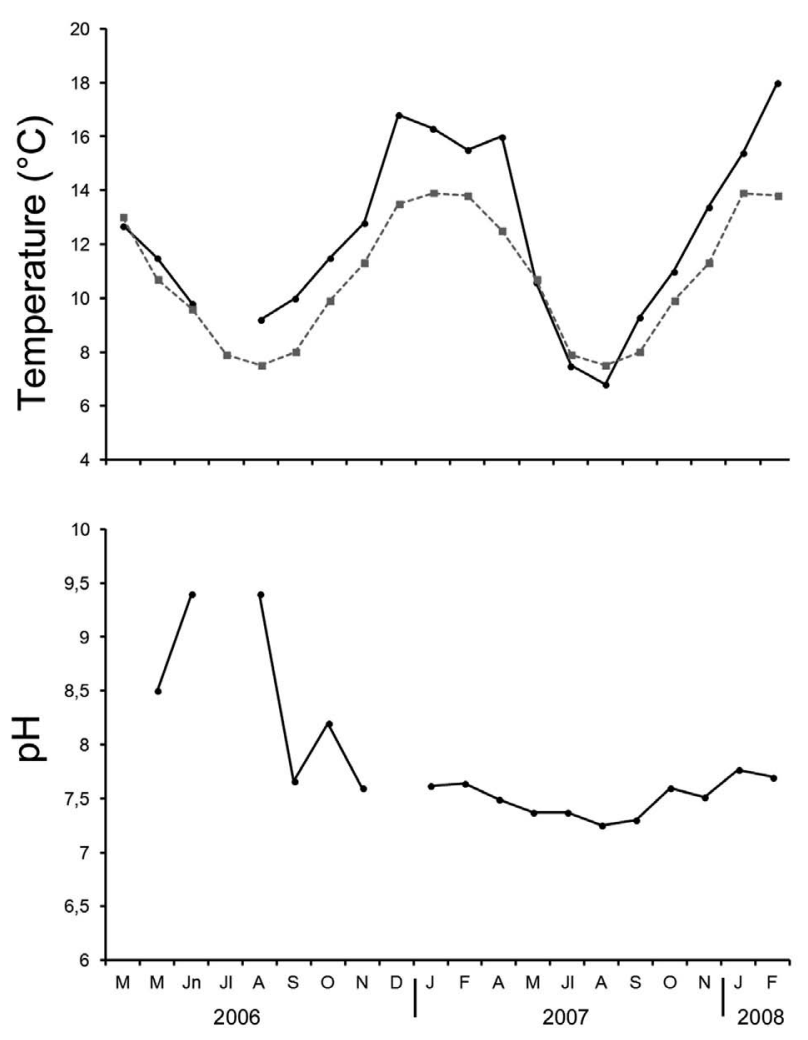

Fig. 4. - Monthly variation in sub-superficial temperature and $\mathrm{pH}$ of water in Bahía Bustamante (black line) between March 2006 and February 2008. Mean temperature of superficial water is indicated by a grey line (Servicio de Hidrografía Naval 2008).

in temperature and $\mathrm{pH}$ are shown in Figure 4. Salinity showed no significant variations, ranging between 33.8 and 34.4. Substrates were dominated by fine (4 samples) and medium (11 samples) sand. Only three samples had a preponderance of gravel and two had rock substrate. Soft bottoms were mainly occupied by $G$. gracilis, while the alien alga $U$. pinnatifida was the most abundant alga in hard bottoms. However, the algal assemblage of samples was variable during the study period and some samples without algal coverage were taken (Fig. 5).

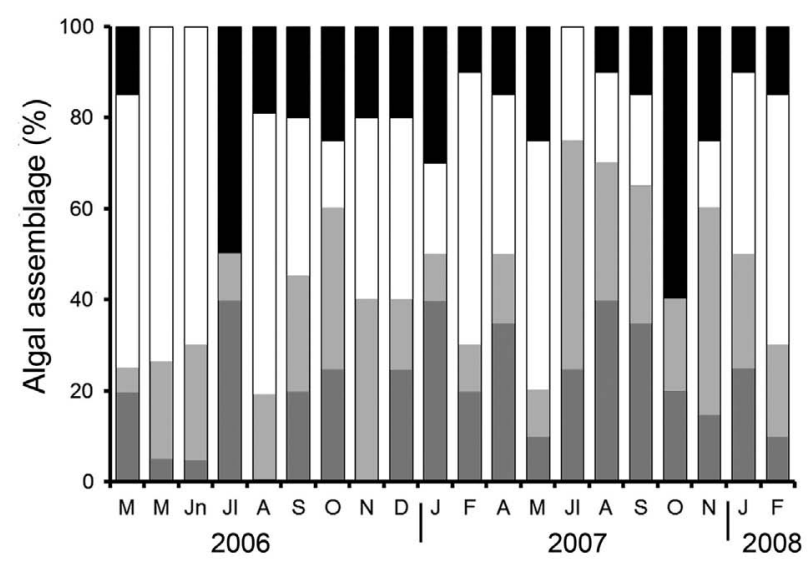

Fig. 5. - Algal assemblage composition of samples: a, samples without algae (dark gray); b, samples with dominance (more than $70 \%$ of total algal biomass) of Gracilaria gracilis (light grey); c, samples with dominance of other macroalgae (white); and d; samples with mixed composition (black).

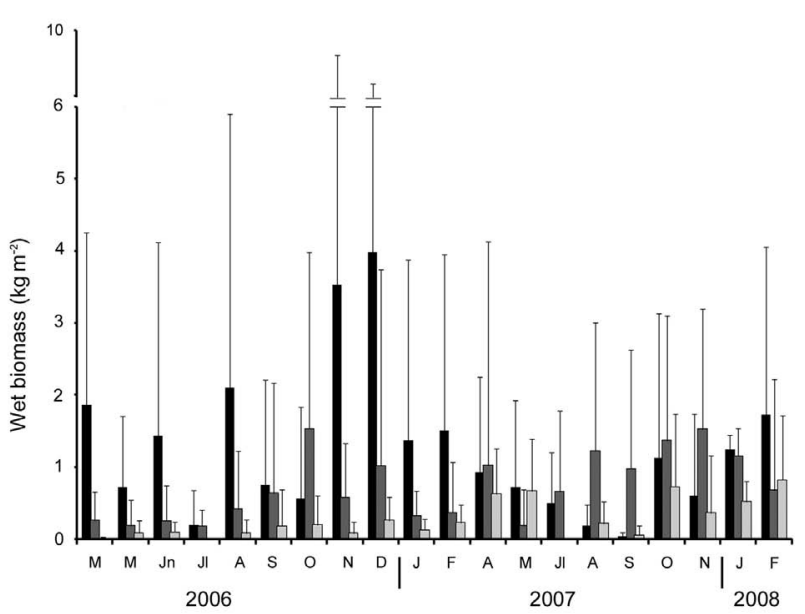

Fig. 6. - Monthly variation of the wet biomass of Gracilaria gracilis (black), other macroalgae (dark gray) and epiphytes of G. gracilis (light grey). Standard error bars are shown.

Gracilaria gracilis was the most abundant macroalga. Mean biomass of G. gracilis ranged between 3.98 $\mathrm{kg} \mathrm{m}^{-2}$ in December 2006 and $0.02 \mathrm{~kg} \mathrm{~m}^{-2}$ in September 2007. Undaria pinnatifida was the most abundant among the other macroalgae of Bahía Bustamante (Fig. 6). Other macroalgae commonly found were Cladostephus spongiosus, Ceramium virgatum, Neosiphonia harveyi and Codium fragile. The most abundant largesize epiphytes of G. gracilis were Sphacelaria fusca, Halopteris sp., Ceramium virgatum, Neosiphonia harveyi, Polysiphonia abscissa, Acrochaetium spp. and Calothrix confervicola.

Among invertebrate preys of $L$. pentagona, the isopod Idotea balthica, the amphipod Austroregia huxleyana, and the polychaete Platynereis sp. were highly abundant and frequent. Potential predators included fish (Patagonotothen sima, P. cornucola, Ribeiroclinus eigenmanni and Agonopsis chiloensis) and large-size crabs (Carcinus maenas, Ovalipes trimaculatus and Peltarion spinosulum). Thirteen decapod species, mostly represented by juvenile stages, were found (Table 4).

Table 4. - Presence of decapod species in Bahía Bustamante between March 2006 and February 2008.

\begin{tabular}{|c|c|c|c|}
\hline & Mature & Juvenile & $\mathrm{N}$ \\
\hline \multicolumn{4}{|l|}{ Family Epialtidae } \\
\hline Leucippa pentagona & $\mathrm{x}$ & $\mathrm{x}$ & 1218 \\
\hline Libidoclaea granaria & - & $\mathrm{x}$ & 13 \\
\hline \multicolumn{4}{|l|}{ Family Inachidae } \\
\hline Eurypodius latreillei & - & $\mathrm{x}$ & 13 \\
\hline \multicolumn{4}{|l|}{ Family Inachoididae } \\
\hline Leurocyclus tuberculosus & - & $\mathrm{x}$ & 24 \\
\hline \multicolumn{4}{|l|}{ Family Varunidae } \\
\hline Cyrtograpsus angulatus & $\mathrm{x}$ & $\mathrm{x}$ & 48 \\
\hline Cyrtograpsus altimanus & $\mathrm{x}$ & $\mathrm{X}$ & 52 \\
\hline \multicolumn{4}{|l|}{ Family Hymenosomatidae } \\
\hline Halicarcinus planatus & $\mathrm{x}$ & $\mathrm{x}$ & 172 \\
\hline \multicolumn{4}{|l|}{ Familia Atelecyclidae } \\
\hline Peltarion spinosulum & $\mathrm{x}$ & $\mathrm{x}$ & 38 \\
\hline \multicolumn{4}{|l|}{ Familia Portunidae } \\
\hline Carcinus maenas & - & $\mathrm{x}$ & 2 \\
\hline Ovalipes trimaculatus & $\mathrm{x}$ & $\mathrm{x}$ & 4 \\
\hline \multicolumn{4}{|l|}{ Familia Paguridae } \\
\hline Pagurus comptus & $\mathrm{x}$ & - & 13 \\
\hline \multicolumn{4}{|l|}{ Familia Galatheidae } \\
\hline Munida gregaria & - & $\mathrm{x}$ & 7 \\
\hline \multicolumn{4}{|l|}{ Familia Solenoceridae } \\
\hline Pleoticus muellieri & - & $\mathrm{X}$ & 9 \\
\hline
\end{tabular}


Table 5. - Morisita standardized index (MSI) to evaluate aggregation of Leucippa pentagona. Aggregated behaviour is suggested if $\mathrm{MSI}>0.5$

\begin{tabular}{cc}
\hline Interest group & MSI \\
\hline Recruits & 0.512 \\
Juveniles & 0.506 \\
Matures & 0.519 \\
Ovigerous & 0.513 \\
\hline
\end{tabular}
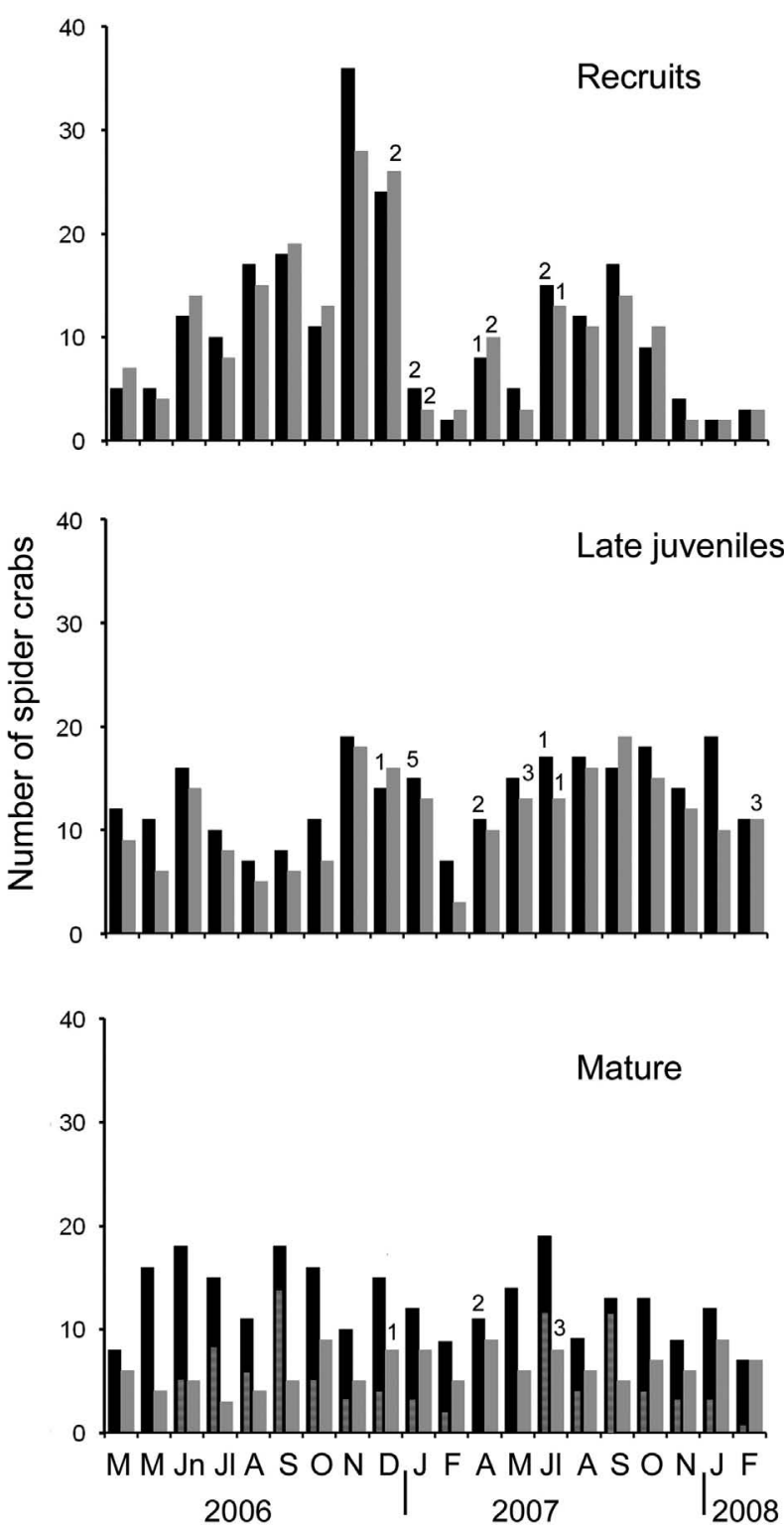

Fig. 7. - Abundance of Leucippa pentagona grouping in recruits, late juveniles and mature crabs. Female (black) and male (grey). Abundance of ovigerous females is indicated by a gray line for mature crabs. Numbers above the bars indicate the number of postmoult crabs.

\section{Spider crab distribution}

Leucippa pentagona was the most abundant crab in the area (see Table 4), with sizes ranging between 2.2 $\mathrm{mm}$ and $34.6 \mathrm{~mm} \mathrm{CL}$. Abundance of recruits was higher at the end of spring 2006 and lower in the following months. However, recruit abundance can be underestimated because the low crab size was lower than the
Table 6. - Summary of redundancy analysis ordination results for biological and environmental variables. Cumulative percentage variance of species data (CPVSD). Cumulative percentage variance of species-environment relation (CPVSER).

\begin{tabular}{lcccc}
\hline & Axes I & Axes II & Axes III & Axes IV \\
\hline Eigenvalues & 0.226 & 0.028 & 0.006 & 0.002 \\
Spp-environment correlation & 0.674 & 0.358 & 0.247 & 0.227 \\
CPVSD & 22.6 & 25.3 & 26.0 & 26.2 \\
CPVSER & 85.8 & 96.4 & 98.7 & 99.5 \\
\hline
\end{tabular}

mesh size used in the sampling. Juvenile abundance was higher in 2007 (with the exception of February) than in 2006. In these size classes, male and female abundance was similar. Conversely, mature females were more abundant than mature males. Ovigerous females were found from June to February in each year. Post-moult crabs were found mainly in late summer and autumn (Fig. 7). All the groups of L. pentagona analysed showed a clumped distribution pattern (Table 5).

A preliminary DCCA confirmed that pRDA was the right procedure for this analysis (gradient lengths of axes I and II were 1.68 and 0.92 , respectively) (ter Braak 1995). The following explanatory variables were significant and thus included in the statistical model to explain L. pentagona distribution: drained wet biomass of $G$. gracilis, drained wet biomass of large epiphytes on $G$. gracilis, drained wet biomass of other macroalgae, density of $H$. planatus, density of other decapods, summerness and depth. Variance inflation factors (VIF) in excess of 10 were deemed to be significant evidence of multicollinearity (see Chatterjee and Price 1977). All VIF values were less than 1.5, indicating no collinearity. The cumulative variance percentage of the pRDA axes of the general dataset explained $26.2 \%$ of the data inertia of the species data and $99.5 \%$ of the species-environment relationship (Table 6). In the pRDA biplot of species and environmental factors, the resulting ordination is quite clear (Fig. 8). The smallscale distribution of $L$. pentagona is related to the algal cover provided by $G$. gracilis, their large-sized epiphytes and other macroalgae. No L. pentagona in-

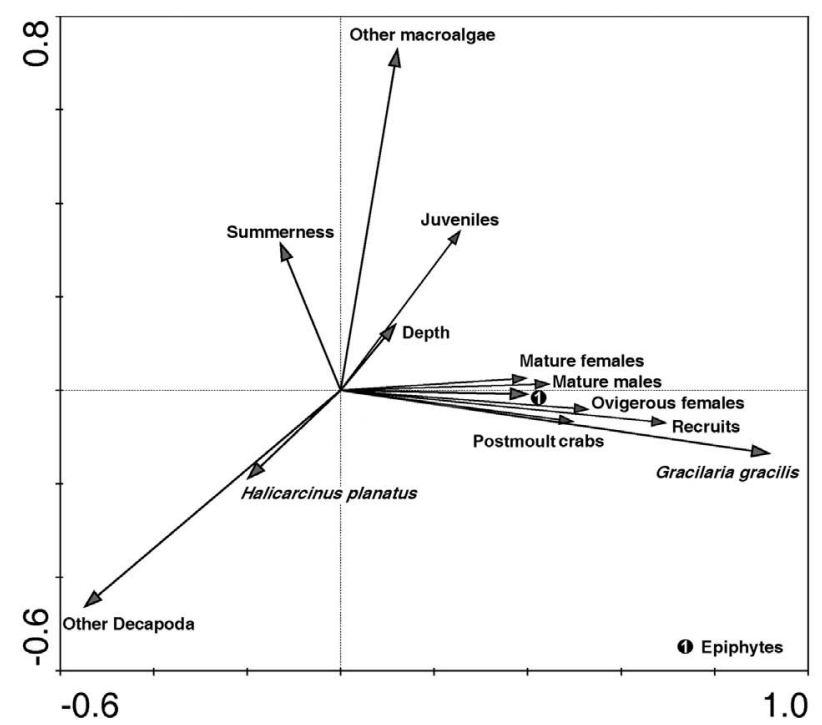

Fig. 8. - Partial redundancy analysis ordination for biological and environmental variables affecting Leucippa pentagona distribution. 
dividuals were found in samples without macroalgae. Early post-moult crabs, ovigerous females, mature and recruits were closely associated with G. gracilis, while juveniles (intermolt) were related in the same way to G. gracilis and other macroalgae. Juveniles were also associated with higher depths, while distributions of other groups of interest were not related to depth within the range analysed $(0-20 \mathrm{~m})$. Juveniles were negatively related to the occurrence of $H$. planatus and other decapod species. The negative relation of recruits and mature crabs to summerness shows that these size classes were less abundant in summer (see Fig. 7).

\section{DISCUSSION}

Epialtidae crabs are mainly herbivorous, with a wide variety of algae in their diet. However, small gastropods, polychaetes, isopods and amphipods are also found in some Epialtidae species studied (Woods and McLay 1994, Stachowicz and Hay 1999, Paiva Barros et al. 2008, Vasconcelos et al. 2009). By contrast, L. pentagona in Bahía Bustamante shows a specialized diet. Over $75 \%$ of the diet of this spider crab is composed of epiphytes of G. gracilis, in particular Sphacelariales. A high consumption of Sphacelariales determines that the diet composition of L. pentagona shows no differences across seasons, sex and size class. It is interesting to note that Sphacelariales are not the most abundant epiphytes of G. gracilis in Bahía Bustamante (Martin et al. 2013). There is some evidence that temporal predictability, algal morphology and organic content are important factors to explain the preferences of mesograzers. Several marine invertebrates prefer algae with low seasonal variation (Paine and Vadas 1969). This fact was particularly observed in the spider crab Mycrophyris bicornutus (Kilar and Lou 1984) and has been suggested to account for the algal preferences of Notomithrax ursus (Woods and McLay 1994) and Acanthonyx scutiformis (Vasconcelos et al. 2009). Martin et al. (2013) reported a low seasonal variation of Sphacelariales biomass in Bahía Bustamante. On the other hand, many spider crab species prefer branched algae as food because they are presumably easier to cut and manipulate (Woods and McLay 1994, CruzRivera 2001, Cruz-Rivera and Friedlander 2011). A recent study has shown that the algal morphology of Gracilaria cornea is one of the most important traits in the feeding choice of the spider crab Acanthonyx lunatus (Cruz-Rivera and Friedlander 2013). The epiphytes Sphacelaria fusca and Halopteris sp. are finely branched algae, which can help to explain its high abundance in the diet of L. pentagona. Moreover, these species had the highest organic content (AFDM) of all the algae analysed in this study. AFDM is often correlated with more specific nutritional traits (Neighbors and Horn 1991, Stachowicz and Hay 1999, Cruz-Rivera and Hay 2001, Cruz-Rivera and Friedlander 2011). For example, Neighbors and Horn (1991) reported this correlation in 22 algal species of California. Therefore, the high consumption of Sphacelariales could be explained by its higher organic content, its low seasonal variation, and its morphology.
Feeding on epiphytes may be indirectly beneficial for the algal host because of the removal of epiphytes (Stachowicz and Hay 1996, Mancinelli and Rossi 2001), inducing secondary metabolites that might be a deterrent to larger grazers (Toth and Pavia 2007), providing nutrients in excretory products (Bracken et al. 2007), or contributing to spore dispersal (Buschmann and Vergara 1993). Moreover, mesograzers that feed on epiphytes could be economically favourable for commercial algal species such as Gracilaria spp. (Shacklock and Doyle 1983, Anderson et al. 1998). The feeding preferences of $L$. pentagona may be beneficial for $G$. gracilis and could have important implications for the subtidal community of Bahía Bustamante. The annual production of $G$. gracilis has dropped significantly in the last few years (Martin et al. 2011). This decrease could be related to the high abundance of epiphytes and their negative effects on the host (Martin et al. 2013). Given the high abundance of L. pentagona and the high abundance of epiphytes in its diet, we consider that L. pentagona can contribute to the control of epiphytes in beds of Bahía Bustamante.

Habitat selection of mesograzer species can be closely linked to feeding preferences, but algae that provide the best refuge may not be the most palatable (Nicotri 1980, Duffy and Hay 1994, Mancinelli and Rossi 2001). Experimental evidence has shown that species of the genus Gracilaria are potential food resources for isopods and amphipods, but these species prefer to feed on other algae (Mancinelli and Rossi 2001). However, Cruz-Rivera and Friedlander (2011) demonstrated that the spider crab A. lunulatus consumes more $G$. lemaneiformis than other macroalgae offered. In this study, consumption of the red algae $G$. gracilis was low throughout the study period (overall $\mathrm{RA}=2 \%)$, with a low winter increase ( $\mathrm{RA}=4.17 \%)$. In addition, laboratory observations have confirmed that, if $G$. gracilis is the only food resource offered, it constitutes palatable food for crabs (Varisco, unpublished data). Thalli of G. gracilis are tender and lack chemical defenses, which are traits that can favor their palatability. However, AFDM in G. gracilis is lower than in Sphacelariales and could account for its low relative abundance and frequency of occurrence. However, this does not preclude the possibility that other nutritional traits not considered in this study could be involved in the negative selection of $G$. gracilis.

Structurally complex microhabitats such as seagrass beds, kelp forests, algae and mussel beds are favorable for the development of crabs because they help to minimize predation risk and provide food resources. There is extensive information of decapod species associated with complex vegetation assemblages (e.g. Hines 1982, Herrkind and Buttler 1986, García-Raso and Fernández-Muñoz 1987, Perkins-Visser et al. 1996, López De La Rosa et al. 2006, Daly and Konar 2010). Crabs of the family Epialtidae are commonly found in seaweed assemblages of the subtidal zone. Hines (1982) studied the distribution pattern of five Epialtidae species in kelp forests of California. Vernet-Cornubert (1958) documented the presence of Pisa tetraodon in subtidal macroalgal assemblages along the coast of Monaco. 
This species and juveniles of $P$. carinimana have been reported to be associated with the red alga Mesophylum lichenoides in southern Spain (García-Raso and Fernández-Muñoz 1987). The spider crab Acanthonyx scutiformis inhabits subtidal algal beds on Brazilian coasts (Monteiro-Teixeira et al. 2009). In Argentina, L. pentagona has been found in complex habitats such as algal and mytilid banks (Boschi et al. 1992). Our results show that $L$. pentagona is closely associated with $G$. gracilis patches that provide shelter and food. In the subtidal environment of Bahía Bustamante, $G$. gracilis beds represent the most structurally complex habitat available to spider crabs and other benthic invertebrates.

The microhabitat selection of crustacean decapods can have seasonal and ontogenetic variations. Ontogenetic shifts in microhabitat preference may be due to different shelter or food requirements (Herrkind and Buttler 1986, Robinson and Tully 2000, Vinuesa et al. 2011). In this study, the analysis of the spatial distribution shows that recruits, mature, ovigerous and post-moult crabs are closely related to G. gracilis and its epiphytes, while juveniles occupy a wide habitat, associated with a high biomass of other macroalgae and G. gracilis. Diet analysis suggests that the feeding preferences are not the cause of the spatial segregation of juveniles, which could be related to different shelter requirements. Refuge requirements increase in periods or developmental stages in which crabs are more vulnerable to predation, such as recruitment, moult and early post-moult or female incubation. The relevance of G. gracilis patches as shelter for L. pentagona is suggested by a) the positive relationship between abundance of ovigerous females and biomass of G. gracilis, b) the close association between abundance of postmoult individuals (including post-moult juveniles) and G. gracilis biomass, and c) larger densities of recruits in algal beds.

Approximately $50 \%$ of crabs in the diet analysis had high-fullness levels (classes 3 and 4), suggesting an extensive foraging effort. Trade-off between foraging effort and predation vulnerability is widely known. In this work, feeding at protected sites provided by $G$. gracilis beds could minimize crab predation. The high structural complexity of $G$. gracilis might be the main determinant of interaction between L. pentagona and this alga. High consumption of $G$. gracilis epiphytes allows a high foraging rate in safe living habitats. In addition, this feeding strategy contributes to conserving the microhabitat integrity and could be favorable to G. gracilis development.

\section{ACKNOWLEDGEMENTS}

We thank Patricia Leonardi and Alicia Boraso for their collaboration in field sampling. This work was partially done under the Project granted by the Consejo Nacional de Investigaciones Científicas y Técnicas CONICET PIP N 5045 "Evaluación del estado reproductivo y sanitario del alga agarófita Gracilaria gracilis (Rhodophyta) en Bahía Bustamante (Chubut)". We also thank Damian Gil for his constructive comments.

\section{REFERENCES}

Anderson B., Smit A., Bolton J. 1998. Differential grazing effects by isopods on Gracilaria gracilaris and epiphytic Ceramium diaphanum in suspended raft culture. Aquaculture 169: 99-109. http://dx.doi.org/10.1016/S0044-8486(98)00322-6

Boschi E., Fischbach C., Iorio M. 1992. Catálogo ilustrado de los crustáceos estomatópodos y decápodos marinos de Argentina. Frente Marítimo 10: 7-94.

Boström C., Mattila M. 1999. The relative importance of food and shelter for seagrass associated invertebrates - a latitudinal comparison of habitat choice by isopod grazers. Oecologia 120: $162-170$. http://dx.doi.org/10.1007/s004420050845

Bracken M., González-Dorantes C., Stachowicz J. 2007. Wholecommunity mutualism: associated invertebrates facilitate a dominant habitat-forming seaweed. Ecology 88: 2211-2219. http://dx.doi.org/10.1890/06-0881.1

Buschmann A.H., Vergara P. 1993. Effect of rocky intertidal amphipods on algal recruitment: a field study. J Phycol. 29: 154-159. http://dx.doi.org/10.1111/j.0022-3646.1993.00154.x

Chatterjee S., Price B. 1977. Regression Analysis by examples. John Willey and Sons, New York, 228 pp.

Clarke K., Warwick R. 2001. Changes in marine communities: an approach to statistical analysis and interpretation. Primer-e Ltd, pp. 0-1 to $17-18$.

Cruz-Rivera E. 2001 Generality and specificity in the feeding and decoration preferences of three Mediterranean crabs. J. Exp. Mar. Biol. Ecol. 266: 17-31. http://dx.doi.org/10.1016/S0022-0981(01)00334-3

Cruz-Rivera E., Hay M. 2000. Can quantity replace quality? Food choice, compensatory feeding, and fitness of marine mesograzers. Ecology 81: 201-219.

http://dx.doi.org/10.1890/0012-9658(2000)081[0201:CQRQF C]2.0.CO;2

Cruz-Rivera E., Hay M. 2001. Macroalgal traits and the feeding and fitness of an herbivorous amphipod: the roles of selectivity, mixing, and compensation. Mar. Ecol. Prog. Ser. 218: 249- 266. http://dx.doi.org/10.3354/meps218249

Cruz-Rivera E., Friedlander M. 2011. Feeding preferences of mesograzers on aquacultured Gracilaria and sympatric algae. Aquaculture 322-323: 218-222. http://dx.doi.org/10.1016/j.aquaculture.2011.09.035

Cruz-Rivera E., Friedlander M. 2013. Effects of algal phenotype on mesograzer feeding. Mar. Ecol. Prog. Ser. 490: 69-78. http://dx.doi.org/10.3354/meps10429

Daly K., Konar B. 2010. Temporal trends of two spider crabs (Brachyura, Majoidea) in nearshore kelp habiats in Alaska, U.S.A. Crustaceana 83: 659-669.

Duffy J., Hay M. 1991. Food and shelter as determinants of food choice by an herbivorous marine amphipod. Ecology 75: 1286-1298. http://dx.doi.org/10.2307/1941102

Duffy J., Hay M. 1994. Herbivore resistance to seaweed chemical defense: the roles of mobility and predation risk. Ecology 75: 1304-1319. http://dx.doi.org/10.2307/1937456

García-Raso J., Fernández-Muñoz R. 1987. Estudio de una comunidad de crustáceos decápodos de fondos coralígenos del alga Mesophyllum lichenoides del sur de España. Inv. Pesq. 51: 301-322.

Hammann M., Buchhloz B., Karez R., et al. 2013. Direct and indirect effects of Gracilaria vermiculophylla on native Fucus vesiculosus. Aquat. Inv. 8: 121-132. http://dx.doi.org/10.3391/ai.2013.8.2.01

Herrkind W., Butler M. 1986. Factors regulating postlarval settlement and juvenile microhabitat use by spiny lobsters Panulirus argus. Mar. Ecol. Prog. Ser. 34: 23-30. http://dx.doi.org/10.3354/meps034023

Hines A. 1982. Coexistence in a kelp forest: size, population dynamics, and resource partitioning in a guild of spider crabs (Brachyura, Majidae). Ecol. Mon. 52: 179-198. http://dx.doi.org/10.2307/1942610

Hultgren K., Stachowicz J. 2008. Alternative camouflage strategies mediate predation risk among closely related co-occurring kelp crabs. Oecologia 155: 519-528. http://dx.doi.org/10.1007/s00442-007-0926-5

Kilar J., Lou R. 1984. Ecological and behavioural studies of the decorator crab, Microphrys bicornutus Latreille (Decapoda: Brachyura): a test of optimum foraging theory. J. Exp. Mar. 
Biol. Ecol. 74: 157-167.

http://dx.doi.oro/10.1016/0022-0981(84)90083-2

López De La Rosa I., Rodríguez A., García-Raso J. 2006. Seasonal variation and structure of a decapod (Crustacea) assemblage living in a Caulerpa prolifera meadow in Cádiz Bay (SW Spain). Estuar. Coast Shelf Sci. 66: 624-633. http://dx.doi.org/10.1016/j.ecss.2005.11.008

Mancinelli G., Rossi L. 2001. Indirect, size-dependent effects of crustacean mesograzers on the rhodophyta Gracilaria verrucosa (Hudson) Papenfuss: evidence from a short-term study in the lesina lagoon (Italy). Mar. Biol. 138: 1163-1173. http://dx.doi.org/10.1007/s002270100545

Martin L., Boraso A., Leonardi P. 2011. Biomass variation and reproductive phenology of Gracilaria gracilis in a Patagonian natural bed (Chubut, Argentina). J. Appl. Phycol. 23: 643-654. http://dx.doi.org/10.1007/s10811-010-9555-1

Martin L., Boraso de Zaixso A., Miravalles A., et al. 2013. Epiphytism in a subtidal natural bed of Gracilaria gracilis of southwestern Atlantic coast (Chubut, Argentina). J. Appl. Phycol. 25: 1319-1329. http://dx.doi.org/10.1007/s10811-012-9961-7

Moksnes P. 2002. The relative importance of habitat-specific settlement, predation and juvenile dispersal for distribution and abundance of young juvenile shore crabs Carcinus maenas L. J. Exp. Mar. Biol. Ecol. 271: 41-73 http://dx.doi.org/10.1016/S0022-0981(02)00041-2

Monteiro-Teixeira G., Franzoso V., Cobo V., et al. 2009. Population features of the spider crab Acanthonyx scutiformis (Dana 1851) (Crustacea, Majoidea, Epialtidae) associated with rocky-shore algae from southeastern Brazil. Pan-American J. Aquat. Sci. 4: 87-95.

Neighbors M., Horn M. 1991. Nutritional quality of macrophytes eaten and not eaten by two temperate-zone herbivorous fishes: a multivariate comparison. Mar. Biol. 108: 471-476. http://dx.doi.org/10.1007/BF01313657

Nicotri M. 1980. Factors involved in herbivore food preference. J. Exp. Mar. Biol. Ecol. 42: 13- 25 http://dx.doi.org/10.1016/0022-0981(80)90163-X

Paine R., Vadas R. 1969. Calorific values of benthic marine algae and their postulated relation to invertebrate food preference. Mar. Biol. 4: 79-86. http://dx.doi.org/10.1007/BF00347036

Paiva Barros S., Cobo V., Fransozo A. 2008. Feeding habits of the spider crab Libinia spinosa H. Milne Edwards, 1834 (Decapoda, Brachyura) in Ubatuba Bay, Sao Paulo, Brazil. Braz. Arch. Biol. Tech. 51: 413-417. http://dx.doi.org/10.1590/S1516-89132008000200023

Palmer M. 2011. Environmental variables in constrained ordination (e.g. CCA, RDA, DCCA). http://ordination.okstate.edu/envva. htm. (Accesed 18 January 2013)

Perkins-Visser E., Wolcott T., Wolcott D. 1996. Nursery role of seagrass beds: enhanced growth of juvenile blue crabs (Callinectes sapidus) Rathbun. J. Exp. Mar. Biol. Ecol. 198: 155-173. http://dx.doi.org/10.1016/0022-0981(96)00014-7

Pohle G., Marques F. 2003. Zoeal stages and megalopa of Leucippa pentagona $\mathrm{H}$. Milne Edwards, 1833 (Decapoda: Brachyura: Majoidea: Epialtidae) obtained from laboratory culture and a comparison with other epialtid and majoid larvae. Invertebr. Reprod. Dev. 43: 55-70. http://dx.doi.org/10.1080/07924259.2003.9652522

Poore A., Campbell A., Steinberg P. 2009. Natural densities of mesograzers fail to limit growth of macroalgae or their epiphytes in a temperate algal banks. J. Ecol. 97: 164-175. http://dx.doi.org/10.1111/j.1365-2745.2008.01457.x

Rodríguez S., Ojeda F., Inestrosa C. 1993. Settlement of marine benthic invertebrates. Mar. Ecol. Prog. Ser. 97: 193-207. http://dx.doi.org/10.3354/meps097193
Robinson M., Tully O. 2000. Spatial variability in decapod community structure and recruitment in sub-tidal habitats. Mar. Ecol. Prog. Ser. 194: 133-141. http://dx.doi.org/10.3354/meps194133

Shacklock P., Doyle R. 1983. Control of epiphytes in seaweed cultures using grazers. Aquaculture 31: 141-151. http://dx.doi.org/10.1016/0044-8486(83)90308-3

Smit A., Fourie A., Robertson B., et al. 2003. Control of the herbivorous isopod Paridotea reticulata in Gracilaria gracilis tank cultures. Aquaculture 217: 385-396 http://dx.doi.org/10.1016/S0044-8486(02)00412-X

Smith-Gill S. 1975. Cytophysiological basis of disruptive pigmentary patterns in the leopard frog Rana pipiens. II. Wild type and mutant cell specific patterns. J. Morph. 146: 35-54. http://dx.doi.org/10.1002/jmor.1051460103

Stachowicz J., Hay M. 1996. Facultative mutualism between an herbivorous crab and a coralline alga: advantages of eating noxious seaweeds. Oecologia 105: 377-387 http://dx.doi.org/10.1007/BF00328741

Stachowicz J., Hay M. 1999. Reduced mobility is associated with compensatory feeding and increased diet breadth of marine crabs. Mar. Ecol. Prog. Ser. 188: 169-178. http://dx.doi.org/10.3354/meps188169

Taylor R., Brown P. 2006 Herbivory in the gammarid amphipod Aora typica: relationships between consumption rates, performance and abundance across ten seaweed species. Mar. Biol. 149: 455-463. http://dx.doi.org/10.1007/s00227-006-0245-0

ter Braak C.J. 1986. Canonical correspondence analysis: a new eigenvector technique for multivariate direct gradient analysis. Ecology 67: 1167-1179 http://dx.doi.org/10.2307/1938672

ter Braak C.J. 1995. Ordination. In: Jongman R., ter Braak C., van Tongeren O. (eds), Data in Community and Landscape Ecology. Cambridge Univ. Press, pp. 91-173. http://dx.doi.org/10.1017/CBO9780511525575.007

ter Braak C.J., Looman C. 1995. Regression. In: Jongman R., ter Braak C., van Tongeren O. (eds), Data in Community and Landscape Ecology. Cambridge Univ. Press, pp. 29-77. http://dx.doi.org/10.1017/CBO9780511525575.005

Toth G., Pavia H. 2007. Induced herbivore resistance in seaweeds: a metaanalysis. J. Ecol. 95: 425-434. http//dx doi.oro/10.1111/j.1365-2745.2007.01224 x

Varisco M., Vinuesa J. 2011. Reproductive biology of spider crab Leucippa pentagon (Decapoda: Epialtidae), in its southernmost population of the Argentine Sea. Lat. Am. J. Aquat. Res. 39: 471-480. http://dx.doi.org/10.3856/vol39-issue3-fulltext-8

Vasconcelos M., Costa Mendes T., Soares Fortes W., et al. 2009. Feeding and decoration preferences of the Epialtidae crab Acanthonyx scutiformis. Braz. J. Oceanogr. 57: 137-143. http://dx.doi.org/10.1590/S1679-87592009000200006

Vernet-Cornubert G. 1958. Biologie générale de Pisa tetraodon (Pennant). Bull. Inst. Océanogr. Monaco 1113: 1-52.

Vinuesa J., Varisco M., Escriche F. 2011. Settlement and recruitment of the crab Halicarcinus planatus (Crustacea: Decapoda: Hymenosomatidae) in Golfo San Jorge, Argentina. J. Mar. Biol. Ass. UK 91: 681-695. http://dx.doi.org/10.1017/S0025315410001864

Wentworth C. 1922. A scale of grade and class terms for clastic sediments. J. Geol. 30: 377-392. http://dx.doi.org/10.1086/622910

Woods C., McLay C. 1994. Masking and ingestion preferences of the spider crab Notomithrax ursus (Brachyura: Majidae). N. Z. J. Mar. Freshw. Res. 28: 105-111. http://dx.doi.org/10.1080/00288330.1994.9516599 